\title{
Study on the Factors Affecting the Poverty Alleviation and Relocation of Peasant Households-- Based on the Survey Data in Xinrong District of Shanxi Province
}

\author{
Di Chen ${ }^{1, a}$, Guoyan Dong ${ }^{1, b}$, Jing Chen ${ }^{2, c}$, Jie Lv ${ }^{1, d *}$ \\ ${ }^{1}$ Shenyang Agricultural University, Shenyang 110866, China \\ ${ }^{2}$ Liaoning Province Agricultural Mechanism Institute, Shenyang 110161, China \\ aChendi19831213@163.com, b546841818@163.com, 169333333@163.com, dijieluesy@163.com
}

*The corresponding author

Keyword: Poverty Alleviation and Relocation; Peasant Households; Factors

\begin{abstract}
Through the field investigation of Xinrong District in Datong city, the paper uses the binary logstic regression model to deal with the influencing factors. The main factors that influence the willingness of peasant households to relocate are as follows: Age of peasant households, annual net income, main sources of income, cultivated land area, housing construction area, transportation convenience, understanding of policy, satisfaction with compensation. Finally, according to the results of the model, combined with the survey results of farmers' willingness to move, the countermeasures and suggestions are proposed.
\end{abstract}

\section{Introduction}

Since the end of the 20th century, with the government constantly putting forward and adjusting the policy of helping the poor, various poverty alleviation methods have been gradually explored. For example, poverty alleviation in Industrial Development, poverty alleviation and relocation, transfer of employment to alleviate poverty and education poverty alleviation, etc. Compared with other poverty alleviation methods, Poverty Alleviation and Relocation is a special method. It plays an irreplaceable role in the process of poverty alleviation and development in areas with deteriorating ecological environment and imperfect infrastructure. In the early 1980s, China began to explore the implementation of the Poverty Alleviation and Relocation policy. It was mainly implemented in Gansu Province and Ningxia Province in the western region, which helped the local poverty alleviation. However, due to the harsh natural conditions, weak agricultural foundation and imperfect infrastructure in the implementation of the Poverty Alleviation and Relocation Policy, there are still many difficulties in fundamentally solving the poverty problem. For the change of poverty status in such areas, the Poverty Alleviation and Relocation Program is an effective method.

Domestic and foreign research on the factors of peasant migration focuses on personal factors, economic factors, family factors and so on.(Da Vanzo J,1978; Bartel,1979; Greenwood,1971; Richard Leete, 1999) ${ }^{[1]}$. However, there are relatively few related researches on the Poverty Alleviation and Relocation in foreign countries, and domestic scholars have concentrated on the resettlement mode and relocation effect of Poverty Alleviation and Relocation(J.Li, 2016; X.E,Li, 2016; L.Liu, 2013) ${ }^{[2][3][4]}$. At present, domestic research on the development mode of Poverty Alleviation and Relocation is relatively rare, so it is more necessary to conduct in-depth exploration of this poverty alleviation development model. By analyzing the influencing factors of the willingness to move the poor households in Xinrong District, To put forward reasonable policy suggestions for the relocation work according to the influencing factors, and promotes the smooth progress of poverty alleviation and development.

\section{Sample Selection and Data Sources}

This study selected Xinrong District of Datong City, Shanxi Province, and conducted an in-depth 
investigation of farmers using the field questionnaire survey method. A sample of 240 samples was sampled in the villages planned to be relocated in Xinrong District. The questionnaire surveyed the spouses of heads of households or heads of households over the age of 18 years. A representative sample was selected by field questionnaire sampling method, involving a total of 30 villages in five townships. According to poverty alleviation office to build the poor households of the file card, the households to be moved from Poverty Alleviation and Relocation project area will be selected as survey samples. 10 villages were randomly selected from each of the villages, and 24 households were selected. A total of 240 questionnaires were distributed and 231 valid questionnaires, accounting for $96 \%$ of the total questionnaires. Table 1 is an analysis of the willingness of poor households to relocate. Of the 231 poor households, 179 are willing to relocate, accounting for $77.5 \% ; 52$ households are reluctant to relocate, accounting for $22.5 \%$. It shows that poor households actively identify and respond to the policy of Poverty Alleviation and Relocation, and poor households are willing to implement the national policy.

Table 1 Analysis of the survey results of the willingness of poor households to relocate

\begin{tabular}{ccc}
\hline Willingness to relocate & Frequency (household) & Frequency (\%) \\
\hline willing & 179 & 77.5 \\
Unwilling & 52 & 22.5 \\
\hline
\end{tabular}

Source of data: field research

\section{Model Selection and Variable Definition}

The binary logistic regression model was selected to quantitatively analyze the influencing factors of the relocation of poor households. According to actual needs, this study examines the willingness of poor households to move, that is, willing or unwilling. Therefore, the regression model can be expressed as:

$$
\ln \left(\frac{p}{1-p}\right)=\beta_{\mathrm{o}}+\beta_{1} x_{1}+\beta_{2} x_{2}+\cdots+\beta_{i} x_{i}+\varepsilon
$$

In the model of relocation of poor households, the willingness of the poor households to move is the dependent variable. The dependent variable assignment is: "willing" is 1 , and "unwilling" is 0 . The independent variables mainly selected 14 impact factors from individual factors, family factors, housing conditions and policy cognition. Among them, three characteristics were selected for the personal characteristics of the poor households, four variables were selected for the household characteristics of the poor households, four variables were selected for the housing situation, and three variables were selected for the policy cognition. The variables are defined as follows: 
Table 2 Definition of the model of the relocation willingness model of poor households Source of data: field research

\begin{tabular}{|c|c|c|c|}
\hline Variable & Code & Name & Definition \\
\hline Dependent variable & $\mathrm{Y}$ & Willingness to participate & $0=$ Unwilling,$\quad 1=$ willing \\
\hline \multirow{4}{*}{$\begin{array}{l}\text { Personal } \\
\text { characteristics }\end{array}$} & $\mathrm{X}_{1}$ & Gender & $1=$ male,$\quad 2=$ Female \\
\hline & $\mathrm{X}_{2}$ & Age & $1=18 \sim 30$ years old, $2=30 \sim 45$ years old \\
\hline & & & $3=45 \sim 60$ years old, $\quad 4=60$ years old or older \\
\hline & $\mathrm{X}_{3}$ & Education level & $\begin{array}{l}\text { 1=Elementary school and below, } 2=\text { junior high school, } \\
3=\text { High school or secondary school, } 4=\text { College and above }\end{array}$ \\
\hline \multirow[t]{6}{*}{$\begin{array}{l}\text { Family } \\
\text { characteristics }\end{array}$} & $\mathrm{X}_{4}$ & Family population & $\begin{array}{l}1=\text { Less than } 3 \text { people, } 2=3 \sim 5 \text { people, } 3=6 \sim 8 \text { people, } 4=9 \\
\text { or more people }\end{array}$ \\
\hline & $\mathrm{X}_{5}$ & Primary source of income & $0=$ Non-agricultural income,$\quad 1=$ Agricultural income \\
\hline & $\mathrm{X}_{6}$ & Annual net income & $1=$ Less than 2,600 yuan, $2=2600 \sim 3100$ yuan \\
\hline & & & $3=3100 \sim 3600$ yuan, $4=$ More than 3,600 yuan \\
\hline & $\mathrm{X}_{7}$ & Cultivated area & $1=$ Less than 10 acres, $2=10$ to 15 acres , \\
\hline & & & $3=15 \sim 20$ acres, $4=$ More than 20 acres \\
\hline \multirow[t]{6}{*}{ Housing situation } & $\mathrm{X}_{8}$ & Year of construction & $1=$ Less than 5 years, $2=6 \sim 15$ years, \\
\hline & & & $3=16 \sim 30$ years, $4=$ More than 30 years \\
\hline & $\mathrm{X}_{9}$ & Construction cost & $1=$ Less than 5,000 yuan, $2=5000 \sim 10000$ yuan, \\
\hline & & & $3=10000 \sim 15000$ yuan, $4=$ More than 15,000 yuan \\
\hline & $\mathrm{X}_{10}$ & Building area & $\begin{array}{l}1=\text { Below } 80 \mathrm{~m}^{2}, 2=80 \sim 120 \mathrm{~m}^{2}, 3=120 \sim 160 \mathrm{~m}^{2}, 4=\text { More } \\
\text { than } 200 \mathrm{~m}^{2}\end{array}$ \\
\hline & $\mathrm{X}_{11}$ & Traffic convenience & $1=$ Not convenient, $2=$ General convenience, $3=$ convenient \\
\hline \multirow[t]{4}{*}{ Policy cognition } & $\mathrm{X}_{12}$ & Satisfaction with & $1=$ Very dissatisfied, $2=$ Not satisfied, $3=$ general , \\
\hline & & compensation & $4=$ satisfaction, $5=$ Very satisfied \\
\hline & $\mathrm{X}_{13}$ & Whether to promote & $1=$ no, $2=$ occasionally, $3=$ Yes, often \\
\hline & $\mathrm{X}_{14}$ & Policy understanding & $\begin{array}{l}1=\text { Don't understand, } 2=\text { Know a little, } 3=\text { Compare, } 4=\text { very } \\
\text { clear }\end{array}$ \\
\hline
\end{tabular}

\section{Analysis of Model Operation Results}

In this paper, binary logistic regression analysis was performed on 231 valid questionnaires in Xinrong District using spss 19.0. The regression results show that the model has a better fitting effect. From the logistic model running results of the willingness to move poor households, there are 8 significant factors that affect the willingness of poor households to relocate, Among them, age, annual net income, cultivated land area, building floor area, satisfaction degree of compensation and understanding degree are significant at $1 \%$ level, and the main income source and transportation convenience are significant at 5\%. Others The factors also have a certain impact on the farmers' willingness to relocate, but the impact is limited, and the impact is not significant. 
Table 3 Logistic analysis of the influencing factors of poor households' relocation

\begin{tabular}{lrccccc}
\hline \multicolumn{1}{c}{ Explanatory variables } & B & S.E & Wals & df & Sig. & Exp ( B ) \\
\hline Age & -2.138 & .762 & 7.881 & 1 & $.005^{* * *}$ & .118 \\
Primary source of income & -1.775 & .824 & 4.646 & 1 & $.031^{* *}$ & .169 \\
Annual net income & 2.331 & .765 & 9.284 & 1 & $.002^{* * *}$ & 10.292 \\
Cultivated area & -2.064 & .546 & 14.298 & 1 & $.000^{* * *}$ & .127 \\
Building area & -1.754 & .514 & 11.652 & 1 & $.001^{* * *}$ & .173 \\
Convenience & -1.397 & .573 & 5.945 & 1 & $.015^{* *}$ & .247 \\
Compensation satisfaction & 1.802 & .600 & 9.023 & 1 & $.003^{* * *}$ & 6.063 \\
Learn degree & 1.771 & .638 & 7.698 & 1 & $.006^{* * *}$ & 5.875 \\
Constant & 5.101 & 5.272 & .936 & 1 & .333 & 164.106 \\
\hline
\end{tabular}

Note: Only significant variables are listed because of space limitations. “*” “***” “***”indicates that the statistical test reached a level of significance of $10 \%, 5 \%$, and $1 \%$, respectively.

The variables with significant regression results were analyzed. Among them, the influence of the age of poor households on the willingness of farmers to relocate is significantly negatively correlated, indicating that as farmers age, they are less willing to relocate. The regression coefficient of the main source of income is negative, that is, the main source of income of the family is non-agricultural income, and the stronger the willingness of farmers to participate in the promotion of poverty alleviation. The reason may be that the farmers are more lazy on the land, and the farmers whose main source of income is non-agricultural income are less dependent on the land and are more conducive to their relocation. The regression coefficient of annual net income is positive, that is, the higher the annual net income, the more willing to relocate. The higher the annual net income level of the family, the stronger the ability to improve their living conditions and the greater the possibility of relocation. The regression coefficient of cultivated land area and building construction area is negative, indicating that the larger the area is, the less the farmers are reluctant to relocate. The reason is that the cultivated land and houses are the guarantee for the farmers to survive. The farmers will worry about the inconvenience of farming after the relocation and housing. The comfort improvement effect will not be improved. The regression coefficient of the convenience of transportation is negative, indicating that the more convenient the farmer's house is located, the less willing to relocate.

The regression coefficient of farmers' satisfaction with the compensation for relocation is positive, and is significant at the level of $1 \%$. This shows that the government's compensation standard for farmers is directly related to whether the losses after the house demolition of rural households can be reasonably compensated, which is an important factor affecting the relocation of farmers. In addition, farmers' understanding of policies is significantly positive at the level of $1 \%$, indicating that the more farmers understand the relevant policies on relocation, the more they will understand the benefits they bring to their own relocation, and the less they worry about after relocation, the more willing to move.

\section{Policy suggestion}

Based on the questionnaire analysis of Xinrong District, Datong City, Shanxi Province, this paper obtains the influencing factors of farmers' willingness to relocate and analyzes them. The following policy recommendations are proposed:

\section{Strengthening policy publicity}

During the investigation, it was found that the relocation target did not know enough about the policy, and there were still many concerns and confusions. Through on-site reception, symposiums, in-depth interviews with farmers, etc., various measures and methods can be adopted to publicize and report on the Poverty Alleviation and Relocation policies and advanced models in an all-round, multi-level and wide-ranging manner, and deepen the enthusiasm of farmers. Explain a series of policies issued by governments at all levels, strengthen communication between the government and the relocated population, timely understand the ideological status of the farmers, and do a correct guiding work for the farmers' ideas. 


\section{Increase compensation standards}

According to the analysis of farmers' willingness to relocate, the primary reason for farmers' reluctance to relocate is that they are not satisfied with the compensation for relocation. Therefore, it is very necessary to improve the relocation compensation for the smooth progress of relocation. Due to the economic difficulties of poor households, they were unable to afford high renovation costs after the relocation, and some poor households were reluctant to relocate. The provincial and municipal governments should take into account the development status of poverty-stricken areas on the support policies, especially the poverty-stricken and poverty-stricken villages, and in the use of funds, on the financial support policies such as poverty alleviation micro-loans and agricultural loans. Reasonable, reciprocal and appropriate tilting will improve the compensation standards for Poverty Alleviation and Relocation, so that farmers can be more reassured and more comfortable relocation, thus promoting the smooth progress of poverty alleviation work in the whole region.

\section{Improve the financing mechanism}

In order to solve the problem of the shortage of government poverty alleviation funds, it is possible to raise funds more effectively, mainly from two aspects: First, attracting capital from society to poverty alleviation projects. In the construction of the place of residence after the relocation, attracting merchants to stay, such as shopping malls, clinics, farmer's market, etc., will not only attract funds, but also improve infrastructure and facilitate the life of farmers; second, make use of the poor residents to live in the original residence. land. The land is used in various ways. Farmers rent land that is inconvenient to relocate after relocation, and use land resources to increase their income.

\section{Improve the relocation operation mechanism}

On the one hand, the establishment of the Poverty Alleviation and Relocation Leading Group, strictly implementing the project in accordance with the management system, and strengthening the level of organization and strengthening leadership in light of local actual conditions. On the other hand, in order to ensure that farmers can effectively get rid of poverty after relocation, they must play the role of industrial poverty alleviation, relying on the resource advantages and market conditions of the region, and actively explore the creation of new models of poverty alleviation in various industries such as rural tourism, technical training, and cooperatives. Poor households develop benefits and promote the economic and poverty-stricken people in poor villages to increase their income.

\section{Acknowledgement}

Supported by the foundation of General Project of Humanities and Social Science from Ministry of Education(14YJC790010), and Research on Economic and Social Development in Liaoning Province(20181slktqn-60)

\section{Reference}

[1] Da Vanzo J: Does Unemployment Affect Migration?-Evidence from Micro Data .Review of Economics and Statistics(1978)No.60,P504-514.

[2] J.Li and L.Wang: The current situation and countermeasures of poverty alleviation in employment transfer in Anyang County. Farm Economic Management(2016)No.11,P13-15.(In Chinese)

[3] X.E.Li and Q L: Analysis of the Poverty Characteristics and Ecological Protection and Poverty Alleviation Models in the Depressed Areas of Qinba. Journal of Agricultural Modernization(2013)No.4,P408-411.(In Chinese)

[4] L.Liu: Analysis of the Factors Affecting Farmers' Participation in Poverty Alleviation Activities in Poverty-stricken Areas of Xinjiang--An Empirical Analysis Based on Questionnaire Survey of 3000 Farmers. Northwest Population(2013)No.3,P67-73.(In Chinese)

[5] Y.Chen, Y.Wang, F.Z.Wei and R.X.Shi: Implementation Method and Basic Experience of Poverty Alleviation and Relocation in Gansu Province since 2010. Journal of Gansu 
Agriculture(2016)No.22,P12-13+31.(In Chinese)

[6] S.D.Chen, J.Y.Cai and W.M.Liao: An Empirical Analysis of the Effect of Poverty Alleviation and Relocation on Farmers' Poverty Reduction--Based on the Survey of Farmers in the Central Soviet Area of South Anhui Province. Journal of Agro-forestry Economics(2016)No.6, P632-640.(In Chinese)

[7] J.X.Li: Innovative Agricultural Science and Technology? Drive Precision Poverty Alleviation . Agricultural Economic Issues(2016)No. 6,P4-8.(In Chinese)

[8] W.Zhang and X.1.Xia: Analysis of Farmers' Willingness to Participate in New Folk House Construction and Its Influencing Factors--Taking Shahe City of Hebei Province as an Example.Research of Agricultural Modernization(2014)No.6,P733-736.(In Chinese) 